\title{
STUDIES OF PHYSICO-CHEMICAL AND PHARMACO-TECHNOLOGICAL PARAMETERS OF BIOFLAVONOIDS DIOSMIN AND HESPERIDIN
}

\author{
Ye. Borko, I. Kovalevska
}

\begin{abstract}
Незважаючи на підвищений попит на синтетичні лікарські засоби, використання субстанцій рослинного походження є перспективним напрямком розвитку фармачевтичного сектору галузі охорони здоров'я України. Субстанціями рослинного походження, щчо мають широкий спектр дії та можуть використовуватися для лікування захворювань судин, в тому числі $і$ терапії захворювань аноректальної зони $-\epsilon$ діосмін та гесперидин. На фармацевтичному ринку України дані субстанції представлені виключно твердими лікарськими формами, щзо застосовуються для лікування хронічної венозної недостатності. Доцільним є звернення уваги на дослідження складу та технології нової комбінованої лікарської форми з діосміном та гесперидином, щз завдяки високим показникам біодоступності може иілеспрямовано вивільняти діючі речовин саме у місиі розвитку патологічного процес. Визначення властивостей діосміну та гесперидину буде мати суттєвий вплив на технологію отримання нового лікарського засобу $і$ грунтується на комплексному дослідженні.
\end{abstract}

Метою роботи стали фізико-хімічні та фармакотехнологічні дослідження субстанцій діосміну та гесперидину.

Результати. В ході виконання поставленої мети було проведено мікроскопічне дослідження субстанцій з наступною побудовою диференціальної кривої розподілу фракцій, вивчено дериватографічні характеристики речовин, проведено дослідження вологопоглинання та розчинності. Була встановлена недостатня розчинність субстаниій діосміну та гесперидину, та високий поріг критичної деструкиії речовин. Результати мікроскопічного аналізу свідчать про неоднорідний розподіл частинок з превалюванням декількох фракцій у зразку діосміну та наявність агломерації частинок у гесперидину.

Висновки. Таким чином на підставі проведених експериментальних досліджень можна зробити висновок про дочільність подальших досліджень, щчодо покращення властивостей субстаниій. Отримані результати матимуть істотний вплив при розробиі складу та технологї̈ нової лікарської форми з діосміном та гесперидином

Ключові слова: діосмін, гесперидин, фармакотехнологічні показники, мікроскопічне дослідження, диференціальна крива розподілу, вологопоглинання, розчинність, дериватографія

Copyright (C) 2019 Ye. Borko, I. Kovalevska This is an open access article under the CC BY license (http://creativecommons.org/licenses/by/4.0).

\section{Introduction}

The use of medicinal substances of herbal origin are perspective direction for development of pharmaceutical science in Ukraine, even though increased demand for synthetic medicines. There was also a growing interest for using of those substances from a wide range of therapeutic effects and low toxicity. One of the most numeral classes of herbal substances is flavonoids, which is containing in almost all medical plants and have growing demand among patient [1]. These substances are alternative variant to synthetic medicines for treatment of venous diseases, including therapy of affections of anorectal diseases. They can use for treatment pathologies that mentioned above and can show effects such as suppression of local inflammatory response, reduction of venous stasis, improvement of lymphatic outflow and venous tone, etc [2].

According to professional literature, which consist experimental researches, more appropriate is use of flavonoids diosmin and hesperidin as components for treatment of anorectal zone diseases [3]. These substances are quite common flavonoids, which are received from pulp of citrus [4]. The positive aspects from using diosmin and hesperidin in treatment of hemorrhoids can be founded on theory «ischemia-reperfusion». This theory is characterizing the excretion of leucocytes from vascular endothelium in the interstitium; at this time can be exuded oxidants and hydrolyzing agents, which can be reasons of edema and microvascular dysfunction of rectal [5].

The anti-inflammation effect of hesperidin is related to his properties in stimulation of nitric oxide excretion from endothelial cells [6]. The nitric oxide is an important local tissue hormone with wide range of effects from anti-inflammation effects to stimulation of angiogenesis. The diosmin is appertained to classes of flavone, but as pharmaceutical substance it can be obtained as semi-synthetic product from hesperidin. This substance could reduce concentration of leukotriene B4, which take part in process of inflammation reaction [7].

The formulation of approaches to physicochemical and pharmaco-technological research is important for diosmin and hesperidin substances with taking into account modern directions in development of new dosage forms, which can be used in development of 
composition and technology of combine dosage form for the treatment of anorectal diseases.

\section{Planning (methodology) of research}

In the pharmaceutical Ukraine market, the substances of diosmin and hesperidin are presented as solid dosage forms, which can be used for treatment of chronic venous insufficiency. These substances could be used in therapy of diseases of anorectal zone, but low bioavailability of oral administration of drugs cannot provide fast effects [8]. It can be more appropriate to design composition and technology of new combination dosage form, which can purposefully release active substances in the places of progressing pathological process [9].

In order to formulate the main directions of the research methodology, attention should be paid to the dosage form that will be used in the treatment of anorectal diseases. It is appropriate to development composition and technology of suppositories with diosmin and hesperidin. The positive aspects of this dosage form will help to provide the maximum therapeutic effect and facilitate the rapid release of active substances from the dosage form due to the anatomical structure of the anorectal zone and the occurrence of adhesion processes between the suppository and the rectal mucosa [10].

This scientific study should be planned on the study of indicators that will maximize the bioavailability of substances in the anorectal zone. To this end, studies should be conducted to establish solubility, distribution, moisture absorption and thermal stability [11].

\section{Materials and methods}

The objects of this research were diosmin (Tayga (Shanghai) Co., Ltd., China) and hesperidin (Tayga (Shanghai) Co., Ltd., China), which can be studied with microscopic, derivatographic method and for properties of solubility and moisture absorption.

Definition of crystallographic characteristics was carried out with a microscopic method using a Konus Academi Microscope of Italian production with a DLTCam Basic 2MP camera. DLTCamViewer TM software was used to visualize images for definition of the shape and size of particles over time [12]. The crystallographic characteristics of the substances diosmin and hesperidin established on value of the Fere's diameter (Df) and shape factor (k) and sphericity coefficient (Ks) [13]. The microscopically research conducted from increases $90 \mathrm{X}$. The sphericity coefficient was calculated as the ratio of indicators the perimeter of the area circle and the perimeter of the area of the particle substances. These parameters can determine initial structure information of the substances, which can predict technological properties of substances [14].

\section{Result}

Studies of solubility and moisture absorption were carried out according to the methods of SPhU [15].

The studies for indicating solubility of diosmin and hesperidin can predict that substances is not dissolve in water, ethanol, acidic and basic environments (Table 1).

Table 1

Solubility of diosmin and hesperidin in hydrophilic dissolvents

\begin{tabular}{|c|c|c|c|c|}
\hline \multirow{2}{*}{ Dissolvent } & \multicolumn{2}{|c|}{ Diosmin } & \multicolumn{2}{c|}{ Hesperidin } \\
\cline { 2 - 4 } & Index, g/100 ml & Result & Index, g/100 ml & Result \\
\hline Ethanol & $0.443 \pm 0.023$ & Almost insoluble & $0.339 \pm 0.019$ & Almost insoluble \\
\hline Water, $\mathrm{pH}=3$ & $2.123 \pm 0.987$ & Little soluble & $2.087 \pm 0.851$ & Little soluble \\
\hline Water, $\mathrm{pH}=7$ & $0.578 \pm 0.043$ & Almost insoluble & $0.538 \pm 0.034$ & Almost insoluble \\
\hline Water, $\mathrm{pH}=8$ & $2.213 \pm 0.992$ & Little soluble & $2.198 \pm 0.971$ & Little soluble \\
\hline
\end{tabular}

Note: $P=95 \%$

The result of microscopic study of dry substances (Fig.1) show that diosmin is a yellow substance, particles have sphericity form and a linear size of 1 to $1 \mu \mathrm{m}$ in maximum measurements, $\mathrm{Df}=1.28 \mu \mathrm{m}, \mathrm{k}=0.77-0.9 \mu \mathrm{m}$,
$\mathrm{Ks}=0.9$, with numerous debris. The hesperidin has uniform distribution of particles, which capable of agglomeration, and have more numerous particles in size of $0.1 \mu \mathrm{m}, \mathrm{Df}=2 \mu \mathrm{m}, \mathrm{k}=0.78 \mu \mathrm{m}, \mathrm{Ks}=0.9$.
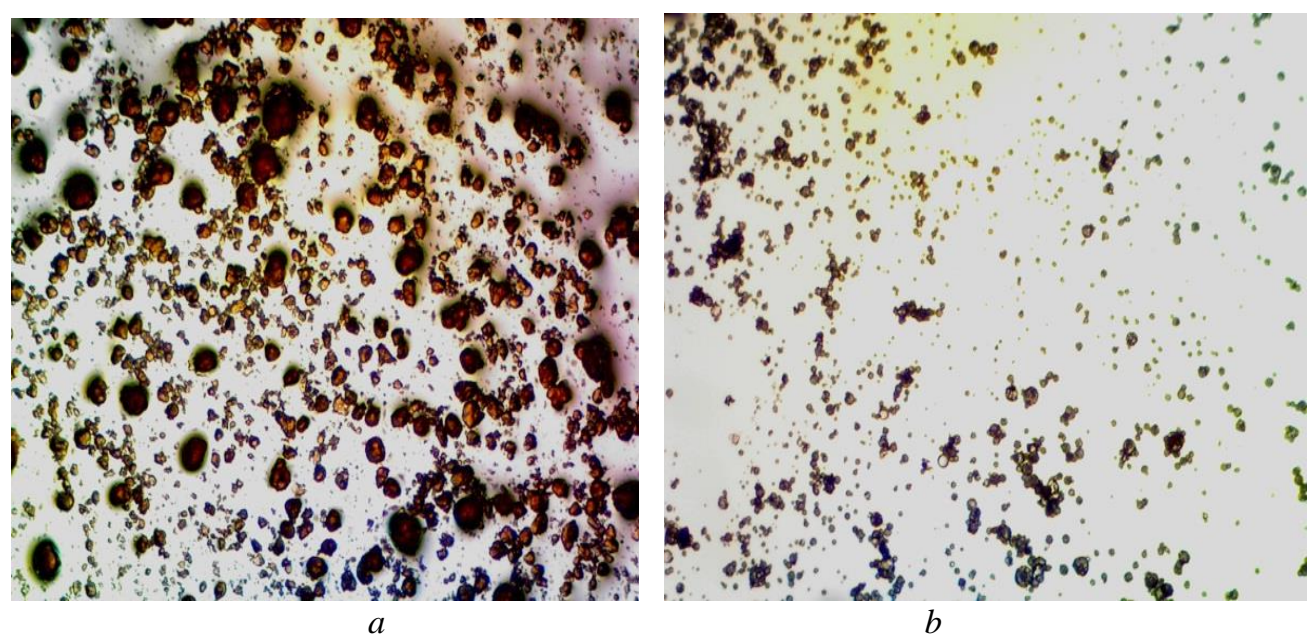

Fig. 1. Photo of dry substances: $a$-diosmin; $b$ - hesperidin 
The result of microscopical analysis shows that substances have different linear values. The diosmin have a few fractions with different distributions of particles. The sphericity coefficient is the same for two substances and appreciated as 1 , it means that substances could be characterized as rounded. This value is im-

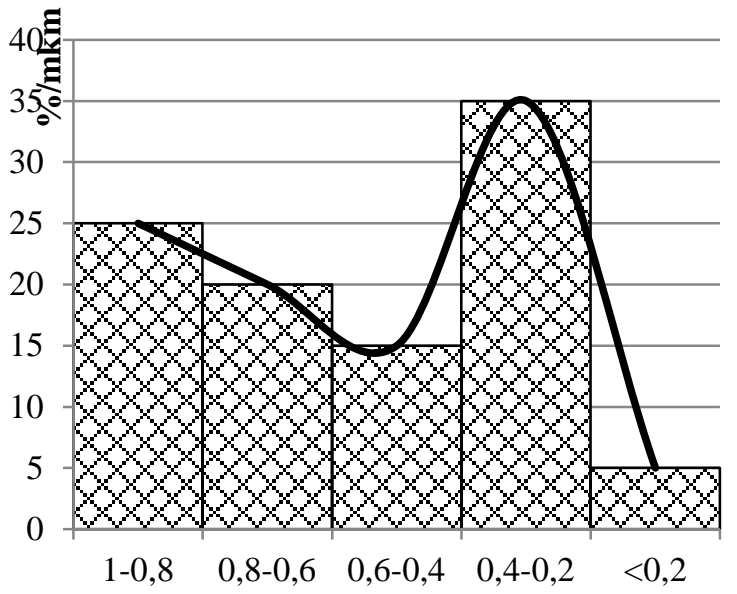

$\delta, \mathbf{m k m}$ portant for calculate the effect of particles on the degree of sedimentation and the rate of release of active substances from the dosage forms.

The resulting data are confirmed by the results of the dispersion analysis of the particle size distribution (Fig. 2).

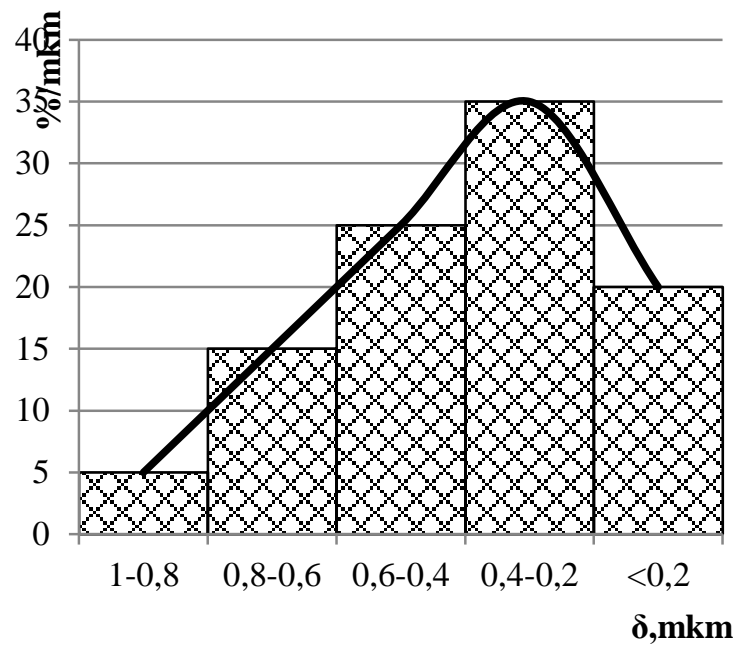

$b$

Fig. 2. Differential curve of particle distribution by microscopic study: $a$ - diosmin; $b$ - hesperidin

As can be seen from data Fig. 2, a sample of hesperidin is obeyed to the law of normal distribution. The differential curve of this substance has one analogue maximum which gradually increases from fraction with a particle size of $1-0.8 \mu \mathrm{m}$ to more numerous fraction $0.4-$ $0.2 \mu \mathrm{m}$ (Fig. 2, $b$ ). The largest area between the differential curve and $x$-line indicates that it has almost equally particle ratio of all fractions. In the sample of diosmin differential curve has two maximums on fractions $1-0.8$ and $0.4-0.2 \mu \mathrm{m}$, which can be characterized that substance as heterogeneous (Fig. 2,a).

The next step was derivatographic analysis of substances diosmin and hesperidin. This method inte- grates thermogravimetry with classical differential thermal analysis and can explore the behavior of individual substances and compositions in programmable heating conditions [16].

The derivatographic research has been conducting with using derivatograph «Paulic-Paulic-Erdei» Q-1500D in in dynamic mode with the heating rate $2.5 \% \mathrm{~min}$. The mass of samples was $300 \mathrm{mg}$. The sensitivity of the device was $100 \mathrm{mkB}$ on the scale of differential thermal analysis (DTA), $100 \mathrm{mg}$ - on thermogravimetric scale (TS) and $500 \mathrm{mkB}$ - on differential thermogravimetric scale (DTG). The result of derivatographic analysis shows on Fig. 3.

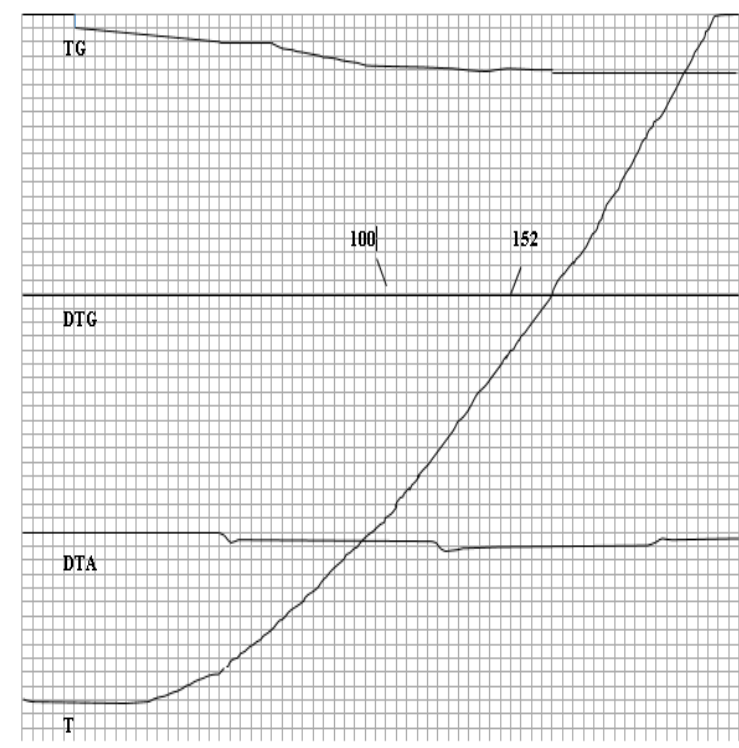

$a$

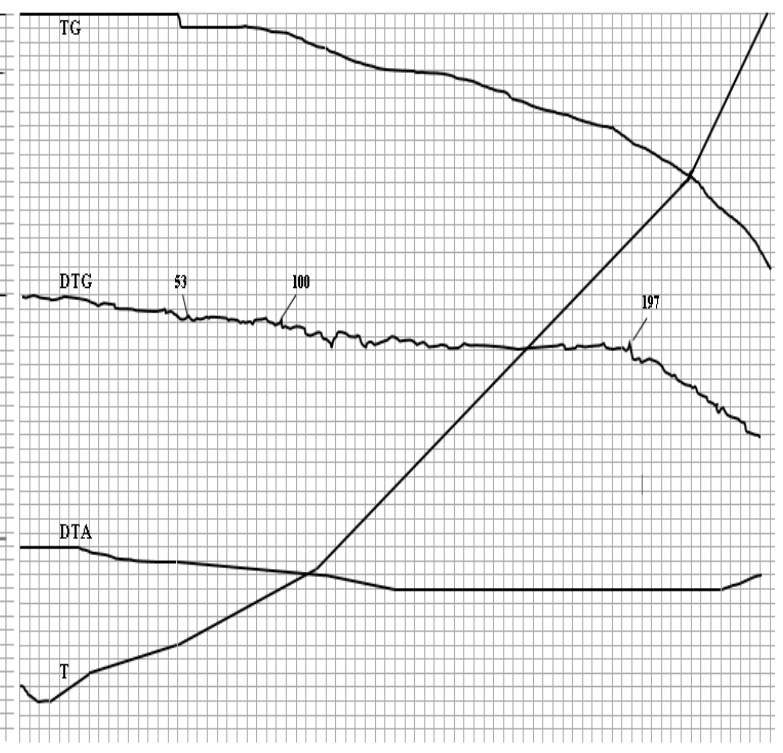

$b$

Fig. 3. Derivatographic research of substances: $a$-diosmin; $b$ - hesperidin 
The moisture absorption of substances was determined by the dynamics of samples mass change that have been placed in the desiccator when constant relative humidity $45,60,75 \%$ was created.

The result of research diosmin show that mass of substance has been increased on $2.13 \%, 4.89 \%, 5.43 \%$ with relative humidity $45,60,75 \%$. The hesperidin is been characterizing mass increased on $2.02 \%, 4.21 \%$, $5.12 \%$ with analogical relative humidity. The substances diosmin and hesperidin are hygroscopic. They quickly absorb moisture, which depends on the humidity of the environment when the experiment was conducted.

\section{Discussion}

Because of the solubility research, it was found that substances belong to IV class of bioavailability, which means these samples need to increase solubility from additional technological techniques and can prove the feasibility of changing the route of administrations of substances into the human body [17].

The result of microscopically analysis shows that substances have different linear values. The diosmin have a few fractions with different distributions of particles. The sphericity coefficient is the same for two substances and appreciated as 1, it means that substances can be characterized as rounded. This value is important for calculate the effect of particles on the degree of sedimentation and the rate of release of active substances from the dosage forms.

The obtained results of derivatographic research show that diosmin (Fig. 3a) characterized by mass decrease already with the onset of heating of the substance, $\mathrm{t}=100{ }^{\circ} \mathrm{C}-\Delta=2,5 \% ; \mathrm{t}=152{ }^{\circ} \mathrm{C}-\Delta=5 \%$; before $\mathrm{t}=250{ }^{\circ} \mathrm{C}$ was stable, thermal reactions was not revealed. The hesperidin (Fig. 3, $b$ ) characterized by mass decrease already with $\mathrm{t}=53{ }^{\circ} \mathrm{C}$; $\mathrm{t}=100{ }^{\circ} \mathrm{C}-\Delta=2,5 \%$; from $\mathrm{t}=197{ }^{\circ} \mathrm{C}$ the substance was destructed, thermal reactions was not revealed.

As the results of moisture research, it was conclude that, the substances of diosmin and hesperidin are hygroscopic. They quickly absorb moisture, which depends on the humidity of the environment when the experiment is conducted.

According to the results of research, it is reasonable to administer excipients for development of new dosage form, because increased humidity in substances can influence on quality of dosage form, their physical and chemical stabilities.

Study limitations. The results that been obtained have some limitations, because the solubility study can indicate necessity for additional technological techniques for the introduction of active substances in suppository basis. It is advisable to carry out additional studies for the solubility of the substances of diosmin and hesperidin in hydrophilic and hydrophobic solvents, because many bases of suppository belong to the hydrophobic type.

The obtained results will be practically useful in conducting studies on the distribution and release of substances of diosmin and hesperidin from the dosage form of suppositories.

\section{Conclusions}

According to the results of the research, advisability of using diosmin and hesperidin in treatment anorectal diseases was found expedient, but low bioavailability of oral administration of drugs cannot provide fast effects. It was indicated that on the pharmaceutical market of Ukraine the substances of diosmin and hesperidin are presented as solid dosage forms, which can be used for treatment chronic venous insufficiency. It was showing necessity of studying their physico-chemical and pharmaco-technological indicators for development composition and technology of new combination dosage form, which can purposefully release active substances in the places of progressing pathological process.

According to the results of microscopic analysis, diosmin has a few fractions with different distributions of particles and numerous debris. The sample of hesperidin has capable of agglomeration, herewith the differential curve show that it has almost equally particle ratio of all fractions. The results of sphericity coefficient can make hypothesis for faster distribution of substances due to the shape close to spherical.

The results of complex physico-chemical and pharmacotechnological researches show insufficient solubility of diosmin and hesperidin, their high hygroscopicity and high critical degradation of substances.

Based on research it can be concluded, that conducted results will have impact on design of the composition and technology of the new dosage form with diosmin and hesperidin.

\section{References}

1. Yang, B., Liu, H., Yang, J., Gupta, V. K., Jiang, Y. (2018). New insights on bioactivities and biosynthesis of flavonoid glycosides. Trends in Food Science \& Technology, 79, 116-124. doi: http://doi.org/10.1016/j.tifs.2018.07.006

2. Borko, Ye. A., Kovalevskaya, I. V. (2018). The urgency of creating a new drug for the treatment of diseases of the anorectal zone with bioflavonoids. Scientific and technological progress and optimization of technological processes for the creation of drugs. Ternopil: TDMU "Ukrmedkniga", 93-94.

3. Palienko, R. K., Yosipenko, M. K. (2005). Comparative analysis of the clinical efficacy of semi-synthetic diosmin in the treatment of acute hemorrhoids. Surgery, 1 (13), 13-20.

4. Li, C., Schluesener, H. (2015). Health-promoting effects of the citrus flavanone hesperidin. Critical Reviews in Food Science and Nutrition, 57 (3), 613-631. doi: http://doi.org/10.1080/10408398.2014.906382

5. Silambarasan, T., Raja, B. (2012). Diosmin, a bioflavonoid reverses alterations in blood pressure, nitric oxide, lipid peroxides and antioxidant status in DOCA-salt induced hypertensive rats. European Journal of Pharmacology, 679 (1-3), 81-89. doi: http://doi.org/10.1016/j.ejphar.2011.12.040

6. Chen, J., Wang, Z.-Z., Kong, L.-L., Chen, N.-H. (2018). Hesperidin. Natural Small Molecule Drugs from Plants. Singapore: Springer, 81-86. doi: http://doi.org/10.1007/978-981-10-8022-7_13 
7. Freag, M. S., Elnaggar, Y. S. R., Abdallah, O. Y. (2013). Development of novel polymer-stabilized diosmin nanosuspensions: In vitro appraisal and ex vivo permeation. International Journal of Pharmaceutics, 454 (1), 462-471. doi: http://doi.org/10.1016/j.ijpharm.2013.06.039

8. Panakanti, R., Narang, A. S. (2015). Impact of Excipient Interactions on Drug Bioavailability from Solid Dosage Forms. Excipient Applications in Formulation Design and Drug Delivery. Cham: Springer, 273-310. doi: http://doi.org/10.1007/978-3-31920206-8_10

9. Kononenko, N. M., Renyova, I. M., Borko, E. A. (2019). Prospects for the creation of suppositories based on diosmin for the treatment of hemorrhoids, proctitis and other proctological diseases. Medicines - human. Current Problems of Pharmacotherapy and Prescription of Medicines. Kharkiv: NFaU, 2, 149-150.

10. Shalaby, K., M. Samy, A., Kassem, A., F. Ibrahim, M., K. Alruwaili, N., M. Ali, H., Elmowafy, M. (2019). Formulation, in vitro and Bioavailability Assessments of Ranitidine Rectal Suppositories. Journal of Pharmaceutical Research International, 1-10. doi: http://doi.org/10.9734/jpri/2019/v30i130262

11. Hua, S. (2019). Physiological and Pharmaceutical Considerations for Rectal Drug Formulations. Frontiers in Pharmacology, 10. doi: http://doi.org/10.3389/fphar.2019.01196

12. Kovalevska, I. V., Borko, Ye. A., Poluian, S. M. (2019). A study of the influence of solvents on crystallographic characteristics of local anesthetics. Annals of Mechnikov Institute, 1, 17-22.

13. Korolev, D. V., Naumov, V. N., Suvorov, K. A. (2005). Determination of the dispersed composition of powders by microscopic method. Saint Petersburg: GOU VPO SPbGTI (TU), 41.

14. Pabst, W., Gregorova, E. (2007). Characterization of particles and particle systems. ICT Prague, 122, 122. ter", 556

15. State Pharmacopoeia of Ukraine (2001). Kharkiv: RIREG, State Enterprise "Scientific Expert Pharmacopoeial Cen-

16. Snezhkin, Y., Petrova, J. (2017). Derivatographic study of dehydration of betanine-containing plant materials and their thermal stability. Scientific Works, 80, 80-89.

17. Kohli, K., Chopra, S., Dhar, D., Arora, S., Khar, R. K. (2010). Self-emulsifying drug delivery systems: an approach to enhance oral bioavailability. Drug Discovery Today, 15 (21-22), 958-965. doi: http://doi.org/10.1016/j.drudis.2010.08.007

Received date 10.09.2019

Accepted date 06.10.2019

Published date 31.10.2019

Yelyzaveta Borko, Postgraduate Student, Department of Industrial Technology of Drugs, National University of Pharmacy, Pushkinska str., 53, Kharkiv, Ukraine, 61002

E-mail: elizborko@gmail.com

Inna Kovalevska, PhD, Associate Professor, Department of Industrial Technology of Drugs, National University of Pharmacy, Pushkinska str., 53, Kharkiv, Ukraine, 61002

E-mail: inga.kovalevskaya@gmail.com 